\title{
Drámapedagógia
}

\section{ALKALMAZOTT SZÍNHÁZ, SZÍNHÁZI NEVELÉS ÉS SZÍNHÁZ-PEDAGÓGIA MAGYARORSZÁGON}

\section{APPLIED THEATRE, THEATRE EDUCATION AND THEATRE PEDAGOGY IN HUNGARY}

\author{
Novák Géza Máté1, Golden Dániel², Cziboly Ádám³ \\ PPhD, egyetemi docens, Eötvös Loránd Tudományegyetem Bárczi Gusztáv Gyógypedagógiai Kar \\ novak.geza@barczi.elte.hu
}

PhD, egyetemi adjunktus, MTA Bölcsészettudományi Kutatóközpont Filozófiai Intézet; Színház- és Filmmüvészeti Egyetem golden.daniel@szfe.hu

${ }^{3} \mathrm{PhD}$, kulturális menedzser, drámatanár, InSite Drama

cziboly@insite-drama.eu

\begin{abstract}
ÖSSZEFOGLALÁS
A Színházi nevelési és színházpedagógiai kézikönyv címmel 2017 őszén megjelent kötetben a hazai alkalmazott színházi műfajokról, a színházi nevelés és színház-pedagógia egészére kiterjedő, 2017 során zajlott kutatás és a kutatáshoz kapcsolódó egyeztetési folyamat eredményeiről számoltunk be. A projektben kiindulásként a Színházi nevelési programok kézikönyve által javasolt alapfogalmakat használtuk. A kutatást és a szakmai egyeztetési folyamatot az InSite Drama koordinálta. Az alkalmazott színház a színházi eseménnyel és a színházi eszköztárral is dolgozik. A művészi eszközöket rendhagyó módon alkalmazza a kihívást jelentő (szociális/etikai) problémák körbejárása során. Vállalkozásaiban szociálisan érzékeny, társadalmi aktivitásra ösztönző, etikailag elkötelezett. A programok témái illeszkednek egyfajta hiánydramaturgiához: olyan jelenségek válnak aktuálisan és korunkra jellemzően színházi alapanyaggá, amelyek színpadi térbe emelésükkel tükrözik az értékvesztettséget, a társadalom anómiás állapotait, a perifériára szorult létezést, egyéni krízist. A színházi nevelési tevékenységek alapvetően két csoportra oszthatóak: azokra, amelyeket megérintett a drámapedagógiai szemlélet, és azokra, amelyeket nem. Előbbibe tartozik egy színházi nevelési produkció vagy az improvizációkból születő diákszínjátszó előadás, utóbbiba a beavató/értelmező színház vagy az egész osztályos feldolgozó beszélgetés. $A z$, hogy egy adott színházi mühely milyen színházi nevelési programokat szervez, nyilvánvalóan nem független a színház funkciójára, küldetésére vonatkozó nézeteitől. A markáns szemléletbeli különbség a művészet és a nevelés feladatát illetően úgy is megfogalmazható, hogy a színház klasszikus értékeit visszük el az értékekben szükölködőknek, avagy a színház eszközével segítjük a kifejezőeszközökben szűkölködőket, hogy megfogalmazzák saját rejtett értékeiket.
\end{abstract}




\section{ABSTRACT}

The Handbook of Theatre in Education and Theatre Pedagogy published in Autumn 2017 reports on the research and conciliation process findings on applied theatrical genres, theatre in education and drama in education that was conducted in Hungary in 2017. We took as our starting points the basic concepts suggested in the Theatrical Education Programs Handbook for the project. The research and the professional negotiation process were coordinated by InSite Drama. Applied theatre uses both theatrical events and theatrical methods as tools, and it applies artistic means in unconventional ways while challenging problematic (social/ethical) issues. It is socially sensitive, socially activating and ethically engaged. The themes of the programmes suit a kind of 'lack in dramaturgy' setup: recent phenomena become actual and typical of the age theatrical topics, their appearance on the stage (or within the body of creators, actors, participants or clients) mirror the loss of values, anomic conditions in society, marginalized existence or individual crises. The educational activities of the theatre are basically divided into two groups: those that are affected by the attitude of drama in education, and those that are not. The former group covers an educational theatre production or a student performance based on improvisation, while the latter would mean an initiating/interpretive theatre or a discussion with a whole class. What educational theatre programme a particular theatre organizes is clearly not independent of the theatre's own ideas of its function and mission. The striking difference between the task of art and education can also be explained as presenting the values of classical theatre to the needy, or supporting persons lacking self-expression to formulate their own hidden values using theatrical tools.

Kulcsszavak: színházi nevelés, színház-pedagógia, drámapedagógia

Keywords: theatre education, theatre pedagogy, drama pedagogy

A Színházi nevelési és színházpedagógiai kézikönyv címmel megjelent kötetben a hazai alkalmazott színházi múfajokról, a színházi nevelés és színház-pedagógia egészére kiterjedő, 2017 során zajlott kutatás és a kutatáshoz kapcsolódó egyeztetési folyamat eredményeiről számoltunk be (Cziboly, 2017). A projektben kiindulásként a Szinházi nevelési programok kézikönyve (Cziboly-Bethlenfalvy, 2013) által javasolt alapfogalmakat használtuk. A kutatást és a szakmai egyeztetési folyamatot az InSite Drama koordinálta. A 2017 októberében megjelent kötetet - a Magyar Tudomány e számában (924-925. oldalon) - Cziboly Ádám, a kiadvány szerkesztője mutatja be.

\section{ALKALMAZOTT SZÍNHÁZ MAGYARORSZÁGON}

A 20. századi alkalmazott, vagyis a nem kizárólag müvészet- és produkcióorientált színház a kritikai, brechti színházi formákból indult el, Paulo Freire pedagógia-kritikai művein, s több fontos más előzmény mellett, a brit színházi nevelési 
előadások (Theatre in Education) módszertanán és Augusto Boal „Elnyomottak Színháza” (Oppressed Theatre) gyakorlatán edződött (Boal, 1979; Golden, 2016; Oblath, 2017).

A hazai alkalmazott színházi gyakorlat a 21. század elején mint kutatás, akció, kísérlet, projekt, művészeti intervenció és társadalomkritikai attitűddel bíró fórum is megjelenik, így egyaránt hatással van a színházművészetre és a társadalomtudományokra. Az alkalmazott színházi formák nem szükségszerủen állnak kívül a müvészeti és nevelési tartományon. A magyarországi társulatok, formációk, mühelyek tevékenységének jellemzője, hogy szociálisan érzékenyek, társadalmi aktivitásra ösztönzők, etikailag és bizonyos müfajokban csoportterápiás szemlélettel is elkötelezettek. Ha azonban az alkalmazott színházi müködések legfontosabb céljait keressük, reflektálnunk kell arra a Jacob Levy Moreno, Bertold Brecht, Augusto Boal, Edward Bond által megrajzolt folyamatra, amely a nézőt cselekvővé, alkotóvá, vagyis résztvevővé tette.

A projektek középpontjában gyakran olyan társadalmi csoportok szereplöi állnak, akik számára a színház lehetőséget ad, hogy hallassák a hangjukat, képviseljék az érdekeiket, közvetítsék az értékeiket, vagy maguk számára méltányosságot, esélyt és közösséget teremtsenek. Másképpen fogalmazva, a színház a közösség érdekében (theatre 'for' community), a közösséggel együtt létrehozott alkotásban (theatre 'with' community) vagy a közösség által (theatre 'by' community) jön létre (Prentki-Preston, 2009, 10.). Az alkotói körök a legkülönbözőbb célok elérése érdekében alkalmaznak színházi formákat, például azért, hogy közelebb kerüljenek bizonyos társadalmi problémák megértéséhez, vagy hatalommal szeretnének felruházni (empowerment) olyan mozgásterében, szabadságában, a társadalmi és kulturális javak elérésében vagy képességeiben akadályozott, elnyomásnak kitett csoportokat, akik nem vagy csak korlátozottan képesek az önálló érdekképviseletre.

Magyarországon a közösségi színház modellje (fórumszínház, elnyomottak színháza, újabban dokumentum- és verbatim színház) legerősebben a szociális színházi formákban és a szociodramatikus aktivitásokban tapasztalható. Az alkalmazott színház a színházi eseménnyel is és a színházi eszköztárral is dolgozik. A müvészi eszközöket rendhagyó módon alkalmazza a kihívást jelentő (szociális/ etikai) problémák körbejárása során. Vállalkozásaiban szociálisan érzékeny, társadalmi aktivitásra ösztönző, etikailag elkötelezett. A programok témái illeszkednek egyfajta hiánydramaturgiához: olyan jelenségek válnak aktuálisan és korunkra jellemzően színházi alapanyaggá, amelyek színpadi térbe emelésükkel (vagy az alkotók, színészek, résztvevők, kliensek testén keresztül) tükrözik az értékvesztettséget, a társadalom anómiás állapotait, a perifériára szorult létezést, egyéni krízist.

Az alábbi táblázatban a különböző színházi eljárások terápiás, szociális, közösségi és pedagógiai területeken való lehetséges csoportosítása látható. Az azo- 
nos színú cellák a területek közötti lehetséges átfedéseket/átjátszásokat jelenítik meg a müfaj, a célok és az elérni kívánt célcsoportok tekintetében. Vitaindítónak szánt, bővíthető dobozok ezek: kísérlet az alkalmazott színházi eljárások terápiás, szociális és pedagógiai területeken való elhelyezésére.

1. táblázat. Kísérlet az alkalmazott színházi eljárások, társadalmi beavatkozások terápiás, szociális, közösségi és pedagógiai területeken való elhelyezésére (Novák, 2017, 73-74.)

\begin{tabular}{|c|c|c|}
\hline \multicolumn{3}{|c|}{ ALKALMAZOTT SZÍNHÁZI FORMÁK (APPLIED THEATRE) } \\
\hline $\begin{array}{l}\text { TERÁPIÁS ÉS TERÁPIÁS } \\
\text { JELLEGÜ ALKALMAZÁSOK } \\
\text { csoportterápiás, } \\
\text { csoport-pszichoterápiás, } \\
\text { müvészetterápiás } \\
\text { alkalmazások, gyógyitó } \\
\text { színház }\end{array}$ & $\begin{array}{l}\text { TÁRSADALMI } \\
\text { BEAVATKOZÁSOK } \\
\text { müvészeti, közösségi és } \\
\text { szociális alkalmazások és } \\
\text { fejlesztések }\end{array}$ & $\begin{array}{l}\text { PEDAGógIAI ALKALMAzÁSOK } \\
\text { müvészeti és pedagógiai } \\
\text { alkalmazások és fejlesztések }\end{array}$ \\
\hline \multicolumn{2}{|c|}{$\begin{array}{l}\text { Pszichodráma (Psychodrama) } \\
\text { Gyermekpszichodráma, bibliodráma } \\
\text { terápiás szándék, ön-és társismereti, mentálhigiénés } \\
\text { alkalmazások } \\
\text { (a résztvevök, kliensek célja az önismereti kompetencia } \\
\text { szélesitése, a jól-lét és a gyógyulás) } \\
\text { Szervezetfejlesztési célú, workshop-jellegü, közösségépítő } \\
\text { alkalmazások, drámatréning pszichodráma-technikákkal }\end{array}$} & \\
\hline & \multicolumn{2}{|c|}{$\begin{array}{l}\text { Közösségi színház } \\
\text { (Community Theatre) } \\
\text { Fórumszinház, Elnyomottak szinháza, Verbatim színház }\end{array}$} \\
\hline $\begin{array}{l}\text { Drámaterápia (Drama } \\
\text { Therapy) } \\
\text { müvészet- és csoportterápiás, } \\
\text { gyógypedagógiai } \\
\text { alkalmazások } \\
\text { dráma és szinház SNI', } \\
\text { speciális szükségletü } \\
\text { csoportokkal, akadályozott } \\
\text { emberekkel } \\
\text { (a segitők célja a kliensek } \\
\text { önismereti kompetenciájának } \\
\text { szélesitésén keresztül a } \\
\text { reintegráció, rehabilitáció, } \\
\text { reszocializáció, inklúzió és a } \\
\text { fejlesztés/gyógyitás) }\end{array}$ & & \\
\hline
\end{tabular}

${ }^{1}$ SNI: sajátos nevelési igényü 
1. táblázat folytatása

\begin{tabular}{|c|c|c|}
\hline \multicolumn{3}{|c|}{ ALKALMAZOTT SZÍNHÁZI FORMÁK (APPLIED THEATRE) } \\
\hline $\begin{array}{l}\text { Színházterápia (Theatre } \\
\text { Therapy) } \\
\text { müvészet- és csoportterápiás } \\
\text { alkalmazások, } \\
\text { terápiás szándék, } \\
\text { szenvedélybeteg-ellátásban } \\
\text { történö alkalmazások } \\
\text { (a segitők célja a kliensek } \\
\text { önismereti és müvészeti } \\
\text { kompetenciáinak szélesitésén } \\
\text { keresztül a társadalmi } \\
\text { reintegráció, rehabilitáció, } \\
\text { reszocializáció, integráció és } \\
\text { a fejlesztés/gyógyitás) }\end{array}$ & & \\
\hline \multicolumn{2}{|c|}{$\begin{array}{l}\text { Szociális dráma és színház } \\
\text { (Social Drama \& Theatre) } \\
\text { reszocializációs, rehabilitációs célú alkalmazások, } \\
\text { szociális cirkusz, börtönszínház, hajléktalan játszók szinháza, } \\
\text { színház a gyermek- és ifjúságvédelemben } \\
\text { dráma és szinház SNI, speciális szükségletü csoportokkal, } \\
\text { akadályozott emberekkel } \\
\text { (nincsen kimondott terápiás cél, de lehet terápiás hatás/ } \\
\text { hatóerö) } \\
\text { integrációs, szocializációs, reszocializációs célú alkalmazások }\end{array}$} & \\
\hline \multicolumn{2}{|c|}{$\begin{array}{l}\text { Szociodráma (Sociodrama) } \\
\text { Play back színház, szociodramatikus szerepjáték } \\
\text { (nincsen kimondott terápiás cél, de lehet terápiás hatás) } \\
\text { szervezetfejlesztés, közösségépítő alkalmazások, drámatréning }\end{array}$} & \\
\hline & $\begin{array}{l}\text { Performansz színház, } \\
\text { népszerü/szórakoztató } \\
\text { színház } \\
\text { interaktiv improvizációs } \\
\text { szinház } \\
\text { tréningszerü alkalmazások } \\
\text { (Performance Theatre, } \\
\text { Popular Theatre) } \\
\text { müvészeti hatás, politikai, } \\
\text { társadalomkritikai } \\
\text { szándék, szórakoztatás, } \\
\text { szervezetfejlesztés, intézményi } \\
\text { tréning és coaching }\end{array}$ & \\
\hline
\end{tabular}


A színház- és drámapedagógiai kutatás elsősorban a szakirodalom feldolgozására, az alkotómühelyek és programok felkutatására fókuszált. Bemutattuk a dokumentumelemzések eredményeit (beleértve az online-tartalmak, filmek és előadás-felvételek, Facebook- és YouTube-megjelenések vizsgálatát is). A kutatást összegző tanulmányban az alkalmazott színház kulcsszereplőivel rögzített félig strukturált interjúk elemzésének eredményeit és a színházi nevelési szakmai közösség számára tett ajánlásokat fogalmaztuk meg (Novák, 2017, 22-75.).

\section{SZÍNHÁZ ÉS NEVELÉS MAGYARORSZÁGON}

Színház és nevelés kapcsolata korántsem magától értetődő. Voltak persze korok és alkotók, amelyeknek és akiknek múvészi hitvallásában hangsúlyosan megjelent a színház ilyen jellegü szerepvállalása, ám az utóbbi kétszáz évben nem ez volt a jellemző. A színház ma jobbára idegenkedik ettől, s az alkotói és befogadói szuverenitást féltve igen hamar didaxist kiált.

A müvészetpedagógia klasszikus hagyományát radikálisan újraíró, legfrissebb színháztörténeti fordulat az alkalmazott színház fogalmának megjelenése volt. Kricsfalusi Beatrix (2016) az alkalmazottságot a célelvüséggel azonosítja, amelynek mentén az ide sorolható kezdeményezések szembeállíthatóak a hagyományos müvészszínház l'art pour l'art önmagáért valóságával. A színház általános „embernevelő” funkciója persze közhely - ennek reflektálatlan és strukturálatlan jelenléte azonban nem esik egybe, $\mathrm{s}$ főként nem váltja ki a sajátos eljárásait a kijelölt cél elérése érdekében szándékoltan alkalmazó szakterület működését. Itt a színházmüvészet igénybe veszi a pedagógia tapasztalatát, azaz a színházi élményt egy tudatosan szervezett tanulási folyamat részeként gondolja el. A társadalmi/ politikai és a pszichológiai/terápiás feladatvállalás mellett harmadikként fogalmazódhat meg a pedagógiai cél (vö. Bethlenfalvy, 2015; Kiss, 2015; Golden, 2016; Novák, 2016).

Azzal összhangban, ahogyan Szauder Erik (2006) a drámapedagógiát nem puszta módszerként, hanem önálló pedagógiai rendszerként értelmezi, azt is mondhatjuk, hogy a színházi nevelési tevékenységek alapvetően két csoportra oszthatóak: azokra, amelyeket megérintett a drámapedagógiai szemlélet, és azokra, amelyeket nem. Előbbibe tartozik egy színházi nevelési produkció vagy az improvizációkból születő diákszínjátszó előadás, utóbbiba a Ruszt-féle beavató/ értelmező színház vagy az egész osztályos feldolgozó beszélgetés.

Az, hogy egy adott színházi műhely milyen színházi nevelési programokat szervez, nyilvánvalóan nem független a színház funkciójára, küldetésére vonatkozó nézeteitől. A markáns szemléletbeli különbség a művészet és a nevelés feladatát illetően úgy is megfogalmazható, hogy a színház klasszikus értékeit 
visszük el az értékekben szükölködőknek, avagy a színház eszközével segítjük a kifejezőeszközökben szűkölködőket, hogy megfogalmazzák saját rejtett értékeiket.

Mindebből az is következik, hogy a színházi nevelés legtágabb meghatározásában a szemlélet aligha tehető kritériummá, azaz a színházi nevelés kiterjesztett, irányzatok és személyes elköteleződések fölött álló fogalmához akkor juthatunk el, ha sem a színház, sem a nevelés tekintetében nem érvényesítünk elözetes elfogultságokat (Golden, 2017, 76-111.).

\section{KÖSZÖNETNYILVÁNITT́S}

A kutatást a Nemzeti Kulturális Alap támogatta.

\section{IRODALOM}

Bethlenfalvy Á. (2015): Alkalmazott színház. A drámapedagógia és színházi nevelés különböző formáinak bemutatása. In: Bodnár G. - Szentgyörgyi R. (szerk.): Szakpedagógiai körkép. Müvészetpedagógiai tanulmányok. Budapest: ELTE, 79-95. http://metodika.btk.elte.hu/file/ TAMOP_BTK_BMK_4.pdf (Utolsó letöltés: 2017. április 18.)

Boal, A. ([1979] 2000): Theatre of the Oppressed. London: Pluto Press, https://mellonseminaremotions.wikispaces.com/file/view/Boal+Agusto-Theatre+of+the+Oppressed.pdf

Cziboly Á. (szerk.) (2017): Szinházi nevelési és színházpedagógiai kézikönyv. Budapest: InSite Drama, http://www.szinhazineveles.hu/tudastar/cziboly-szerk-2017-szinhazi-nevelesi-es-szinhazpedagogiai-kezikonyv/

Cziboly Á. - Bethlenfalvy Á. (2013): Színházi nevelési programok kézikönyve. Budapest: L'Harmattan Kiadó, http://www.szinhazineveles.hu/tudastar/cziboly-bethlenfalvy-2013-szinhazi-nevelesi-programok-kezikonyve/

Golden D. (2016): A színház mint eszköz a dramatikus nevelésben. In: Görcsi P. - P. Müller P. - Pandur P. - Rosner K. (szerk.): A színpadon túl. Az alkalmazott színház és környéke. Pécs: Kronosz, 57-69.

Golden D. (2017): Színház és nevelés Magyarországon. In: Cziboly Á. (szerk., 2017): Színházi nevelési és színházpedagógiai kézikönyv. Budapest: InSite Drama, 76-111. http://www.szinhazineveles.hu/hirek/letoltheto-a-szinhazi-nevelesi-es-szinhazpedagogiai-kezikonyv/

Kiss G. (2015): „A színház csak ürügy”: a színházi nevelés szemünk előtt be-, át-, szét- és talán megrendeződő diszciplináris tere. In: Balassa Zs. - Görcsi P. - Pandur P. et al. (szerk.): Rendezett tér. Be-, át-, szét-, megrendezett terek a színházban és a drámában. Pécs: Kronosz Kiadó, 209-219.

Kricsfalusi B. (2016): Aktivitás - részvétel - interpasszivitás, avagy van-e nézője az alkalmazott színháznak? In: Görcsi P. - P. Müller P. - Pandur P. - Rosner K. (szerk.): A színpadon túl: Az alkalmazott színház és környéke. Pécs: Kronosz Kiadó, 17-29.

Novák G. M. (2016): Dráma és pedagógia. A drámapedagógia aktuális kérdéseiről. Neveléstudomány, 2, 43-52. http://nevelestudomany.elte.hu/downloads/2016/nevelestudomany_2016_2_ 43-52.pdf. (Utolsó letöltés: 2017. április 18.) 
Novák G. M. (2017): Alkalmazott színház Magyarországon. In: Cziboly Ádám (szerk., 2017): Színházi nevelési és színházpedagógiai kézikönyv. Budapest: InSite Drama, 22-75. http://www. szinhazineveles.hu/wp-content/uploads/2018/01/Szinped_Prog_Final_6.pdf

Oblath M. (2017): Fórumszínház. In: Horváth K. - Oblath M. (szerk.): A Sajátszínház módszerei. Müvészet alapú részvételi kutatás. Budapest: L'Harmattan Kiadó, 137-161.

Prentki, T. - Preston, S. (2009): The Applied Theatre Reader. London-New York: Routledge

Szauder E. (2006): Inkluzív nevelés - drámapedagógia. Kézikönyv a pedagógusképzö intézmények számára. Budapest: Sulinova Kht. 